\title{
A case of ABO-incompatible blood transfusion treated by plasma exchange therapy and continuous hemodiafiltration
}

\author{
Akio Namikawa $^{1}\left[\right.$ - Yuko Shibuya ${ }^{1} \cdot$ Haruki Ouchi $^{1} \cdot$ Hiroko Takahashi $^{1} \cdot$ Yoshitaka Furuto $^{1}$
}

Received: 17 July 2017 / Accepted: 11 January 2018 / Published online: 31 January 2018

(c) The Author(s) 2018. This article is an open access publication

\begin{abstract}
ABO-incompatible blood transfusion is potentially a life-threatening event. A 74-year-old type O Rh-positive male was accidentally transfused with $280 \mathrm{~mL}$ type B Rh-positive red blood cells during open right hemicolectomy, causing ABOincompatible blood transfusion. Immediately after the transfusion, the patient experienced a hypotension episode followed by acute hemolytic reaction, disseminated intravascular coagulation and acute kidney injury. Plasma exchange therapy was performed to remove anti-B antibody and free hemoglobin because they caused acute hemolytic reaction, disseminated intravascular coagulation, and acute kidney injury. Free hemoglobin levels decreased from 13 to $2 \mathrm{mg} / \mathrm{dL}$ for $2 \mathrm{~h}$. Continuous hemodiafiltration was used to stabilize hemodynamics. The patient was successfully treated for acute hemolytic reaction, disseminated intravascular coagulation, and acute kidney injury. Plasma exchange therapy and continuous hemodiafiltration are likely to be effective treatments for ABO-incompatible blood transfusion, and further studies are required to assess this effectiveness in future.
\end{abstract}

Keywords Incompatible blood transfusion - Acute hemolytic reaction - Disseminated intravascular coagulation - Acute kidney injury $\cdot$ Plasma exchange therapy $\cdot$ Continuous hemodiafiltration

$\begin{array}{ll}\text { Abbreviations } \\ \text { AKI } & \text { Acute kidney injury } \\ \text { AST } & \text { Aspartate aminotransferase } \\ \text { CRE } & \text { Carbapenem-resistant enterobacteriaceae } \\ \text { CHDF } & \text { Continuous hemodiafiltration } \\ \text { DIC } & \text { Disseminated intravascular coagulation } \\ & \text { syndrome } \\ \text { FDP } & \text { Fibrin/fibrinogen degradation product } \\ \text { FFP } & \text { Fresh frozen plasma } \\ \text { ICU } & \text { Intensive care unit } \\ \text { LDH } & \text { Lactic acid dehydrogenase } \\ \text { L-FABP } & \text { Liver-type fatty acid-binding protein } \\ \text { MDRP } & \text { Multiple-drug-resistant Pseudomonas } \\ & \text { aeruginosa } \\ \text { NO } & \text { Nitric oxide } \\ \text { PTC } & \text { Peritubular capillaries } \\ \text { PIC } & \text { Plasmin- } \alpha 2 \text { plasmin inhibitor }\end{array}$

Akio Namikawa

akinmkw@gmail.com

1 Department of Hypertension and Nephrology, NTT Medical Center Tokyo, 5-9-22 Higash-Gotanda, Shinagawa-ku, Tokyo 141-8625, Japan
TAT Thrombin-antithrombin complex

T-Bil Total bilirubin

\section{Introduction}

ABO-incompatible blood transfusion often causes acute hemolytic reaction followed by disseminated intravascular coagulation (DIC) and acute kidney injury (AKI). In a report by Kim et al., symptoms occurred in $64 \%$ of the patients who were transfused with $\geq 50 \mathrm{~mL} \mathrm{ABO-incompat-}$ ible blood, and the mortality rate was $17 \%$ [1]. The current treatment consists of prompt discontinuation of the blood transfusion along with anti-DIC treatments, in cases of DIC. However, there are few reports on plasma exchange therapy for ABO-incompatible blood transfusion. We report a case of 74-year-old male, who was accidentally transfused with ABO-incompatible blood, treated by plasma exchange therapy and continuous hemodiafiltration (CHDF). 


\section{Case presentation}

A 74-year-old man was admitted to hospital for the treatment of ascending colon cancer. Previous lower gastrointestinal endoscopy revealed $5-\mathrm{cm}$ lesion in the ascending colon, and the biopsy results confirmed colorectal adenocarcinoma. The staging of tumor was cT1N0M0, making it an ideal candidate for treatment with laparoscopy-assisted partial excision of the ascending colon.

Considering the patient's past medical history, he underwent distal gastrectomy for gastric cancer at 45 years of age and prostatectomy for prostate cancer at 70 years of age. He suffered from chronic hepatitis secondary to hepatitis C. On admission, his medication included candesartan $8 \mathrm{mg}$ and amlodipine $5 \mathrm{mg}$ for hypertension, and allopurinol $100 \mathrm{mg}$ for hyperuricemia. His body weight was $63.7 \mathrm{~kg}$. Blood test findings prior to admission showed microcytic hypochromic anemia with an $\mathrm{Hb}$ of $8.5 \mathrm{~g} / \mathrm{dL}$ with normal platelet count and clotting time (Table 1).

The laparoscopy-assisted partial excision of the ascending colon was eventually converted to laparotomy due to multiple adhesions at 90 min into the operation. Blood transfusion was performed at 180 min into the operation because of increased hemorrhage. The patient's blood type was $\mathrm{O}$ Rh positive; however, he was accidentally transfused with $280 \mathrm{~mL}$ ( 2 units) of type B Rh-positive blood.

At $17 \mathrm{~min}$ after the commencement of the ABOincompatible blood transfusion, the patient's blood pressure decreased from $150 / 70$ to $90 / 40 \mathrm{mmHg}$. There was increased bleeding in the surgical area, and the amount of bleeding increased. Catecholamines were administered, and $1400 \mathrm{~mL}$ (10 units) of type $\mathrm{O}$ blood and $1200 \mathrm{~mL}$ (10 units) of type $\mathrm{AB}$ fresh frozen plasma (FFP) were transfused. At approximately $120 \mathrm{~min}$ after the incompatible blood transfusion, hemoglobinuria was detected.

The surgery was eventually completed, and the patient was transferred to the intensive care unit (ICU) approximately $200 \mathrm{~min}$ after the incompatible blood transfusion. Catecholamine treatment was continued to maintain hemodynamics, and an artificial respiratory treatment was instituted.

Hemoglobinuria suggested a high possibility of acute hemolytic reaction, DIC, and AKI due to the incompatible blood transfusion. Plasma exchange therapy and CHDF were initiated to improve the above-mentioned conditions as soon as the patient entered the ICU. The plasma separator used for plasma exchange therapy was OP-05W (Asahi KASEI). During plasma exchange therapy, 1-1.5 times of the actual plasma volume is generally exchanged. In our case, the patient's body weight was $63.7 \mathrm{~kg}$, his hematocrit was $27.6 \%$, and his plasma volume was $3.23 \mathrm{~L}$ on calculation. However, we used larger amount of FFP because this case was severe. We exchanged 13.84 L FFP and performed plasma exchange therapy for $12 \mathrm{~h}$ while observing the improvement in plasma color and decrease in free hemoglobin levels. On CHDF, the hemofilter used was PUT-09eco (NIPRO), blood flow rate $\left(Q_{\mathrm{b}}\right)$ was $80 \mathrm{~mL} / \mathrm{min}$, dialysis flow rate $\left(Q_{\mathrm{d}}\right)$ was $400 \mathrm{~mL} / \mathrm{min}$, and filtration flow rate $\left(Q_{\mathrm{f}}\right)$ was $300 \mathrm{~mL} / \mathrm{min}$. SUBPACK-Bi (NIPRO) was used for diafiltration and nafamostat mesilate was used as an anti-coagulant. We used UT-1100S (NIPRO) as the hemofilter because of coagulation of the previous hemofilter. We performed CHDF for $23 \mathrm{~h}$. In addition, $7.56 \mathrm{~L}$ type $\mathrm{O}$ red blood cells, $2.55 \mathrm{~L}$

Table 1 Laboratory findings on admission

\begin{tabular}{|c|c|c|c|c|c|}
\hline \multicolumn{2}{|l|}{ Urinalysis } & \multicolumn{2}{|l|}{ Full blood count } & \multicolumn{2}{|c|}{ Biochemistry } \\
\hline Specific gravity & 1.024 & WBC & $5100 / \mu \mathrm{L}$ & $\mathrm{Na}$ & $146 \mathrm{mmol} / \mathrm{L}$ \\
\hline $\mathrm{pH}$ & 5.5 & $\mathrm{RBC}$ & $310 \times 10^{4} / \mu \mathrm{L}$ & $\mathrm{K}$ & $3.8 \mathrm{mmol} / \mathrm{L}$ \\
\hline Protein & - & $\mathrm{Hb}$ & $8.5 \mathrm{~g} / \mathrm{dL}$ & $\mathrm{Cl}$ & $109 \mathrm{mmol} / \mathrm{L}$ \\
\hline Blood & - & Hct & $27.6 \%$ & BUN & $14.8 \mathrm{mg} / \mathrm{dL}$ \\
\hline \multirow[t]{12}{*}{ Bilirubin } & - & $\mathrm{MCV}$ & $89.0 \mathrm{Fl}$ & Cre & $0.85 \mathrm{mg} / \mathrm{dL}$ \\
\hline & & $\mathrm{MCH}$ & $27.4 \mathrm{Pg}$ & $\mathrm{TP}$ & $6.2 \mathrm{~g} / \mathrm{dL}$ \\
\hline & & $\mathrm{MCHC}$ & $30.8 \%$ & ALB & $3.8 \mathrm{~g} / \mathrm{dL}$ \\
\hline & & Plt & $17.9 \times 10^{4} / \mu \mathrm{L}$ & UA & $5.3 \mathrm{mg} / \mathrm{dL}$ \\
\hline & & Coagulation & & T-Bil & $0.5 \mathrm{mg} / \mathrm{dL}$ \\
\hline & & PT & $84 \%$ & LDH & $132 \mathrm{IU} / \mathrm{L}$ \\
\hline & & PT-INR & 1.08 & AST & $18 \mathrm{IU} / \mathrm{L}$ \\
\hline & & APTT & $25.6 \mathrm{~s}$ & ALT & $11 \mathrm{IU} / \mathrm{L}$ \\
\hline & & & & ALP & $237 \mathrm{IU} / \mathrm{L}$ \\
\hline & & & & $\gamma \mathrm{GTP}$ & $25 \mathrm{IU} / \mathrm{L}$ \\
\hline & & & & CK & $88 \mathrm{IU} / \mathrm{L}$ \\
\hline & & & & CRP & $<0.3 \mathrm{mg} / \mathrm{dL}$ \\
\hline
\end{tabular}


type $\mathrm{O}$ platelets, and $12.2 \mathrm{~L}$ type $\mathrm{AB}$ FFP were transfused repeatedly for up to $72 \mathrm{~h}$. Steroid was used to inhibit acute hemolytic reaction, and $2000 \mathrm{mg} /$ day gabexate mesilate, a protease inhibitor, was administered as anti-DIC therapy.

At $420 \mathrm{~min}$ after the incompatible blood transfusion, anemia progressed with a decline in $\mathrm{Hb}$ to $5.8 \mathrm{~g} / \mathrm{dL}$. In addition, increased lactic acid dehydrogenase (LDH), total bilirubin (T-Bil), and aspartate aminotransferase (AST) suggested the presence of hemolytic anemia (Fig. 1a). The platelet count reached $1.8 \times 10^{4} / \mu \mathrm{L}$, fibrin/fibrinogen degradation product (FDP) concentration was $9.7 \mu \mathrm{g} / \mathrm{mL}$, thrombin-antithrombin complex (TAT) was $120 \mathrm{ng} / \mathrm{mL}$, and plasmin- $\alpha 2$ plasmin inhibitor (PIC) complex was $0.4 \mu \mathrm{g} / \mathrm{mL}$ (Fig. 1b). The blood results were consistent with the characteristics of DIC. DIC due to acute hemolytic reaction was responsible for the bleeding tendency, which worsened further post-surgery. The amount of bleeding was $9.13 \mathrm{~L}$ up to $72 \mathrm{~h}$.

At $48-72 \mathrm{~h}$ after the accident, T-Bil and LDH levels decreased and $\mathrm{Hb}$ increased to approximately at $9.0 \mathrm{~g} / \mathrm{dL}$, suggesting improvement in hemolytic anemia. The serum haptoglobin was $26 \mathrm{mg} / \mathrm{dL}$ at $48 \mathrm{~h}$. DIC improved with decreasing TAT when the platelet count was approximately $11 \times 10^{4} / \mu \mathrm{L}$ after plasma exchange therapy and CHDF (Fig. 1b).

Free hemoglobin and anti-B antibody levels were measured over time. After the initiation of the plasma exchange therapy, the level of free hemoglobin decreased rapidly with the color of plasma changing from cloudy yellow to clear yellow (Figs. 1c, 2). Although anti-B antibody levels increased by 256 -fold immediately after the accident, this decreased transiently as the antibody was consumed by the hemolytic reaction. It remained at a low value thereafter, and did not show an increase to its level even on day 7 post-blood transfusion (Fig. 3).

From day 6 after the incompatible blood transfusion, the hemolytic reaction worsened, with increasing T-Bil and LDH levels and a decreasing haptoglobin level. We started to infuse haptoglobin 4000 units/day when the serum haptoglobin was $6 \mathrm{mg} / \mathrm{dL}$ at day 9 . The anti-B antibody levels also increased. The hematoma containing residual B antigens around the liver was suspected to contribute to the worsening of the hemolytic reaction. The hematoma was, thus, surgically drained on day 18. Levels of T-Bil, LDH, haptoglobin, and FDP subsequently improved.

The patient maintained a good urinary output and his initial serum creatinine was $0.76 \mathrm{mg} / \mathrm{dL}$ at the beginning of CHDF. Subsequently, the level of the urinary liver-type fatty acid-binding protein (L-FABP) increased to $39.1 \mu \mathrm{g} /$ $\mathrm{gCre}$, and the serum creatinine was increased to $1.25 \mathrm{mg} / \mathrm{dL}$ with newly onset proteinuria (Fig. 1c). The results suggested AKI. Plasma exchange therapy and CHDF were commenced with subsequent rapid improvement of brown discoloration of urine, and rapid normalization of serum creatinine and L-FABP levels (Fig. 1c).

Ventricular fibrillation occurred on day 24 and treatment for infection due to carbapenem-resistant enterobacteriaceae (CRE) and multiple-drug-resistant Pseudomonas aeruginosa (MDRP) was required for 60 days. Incompatible blood transfusion was completely cured on day 58 because FDP was normal on that day. The patient underwent a long period of rehabilitation upon request of the patient's family. As this was a case of a medical accident, we took considerable care of the patient. The patient was discharged on day 151 after the incompatible blood transfusion.

\section{Discussion}

The rate of mortality from $\mathrm{ABO}$-incompatible blood transfusion reported by Kim et al. [1] and Linden et al. [2] was 14 and $5.5 \%$, respectively. Kim et al. further reported that when $\geq 50 \mathrm{~mL}$ blood was transfused, symptoms occurred in $64 \%$ of the patients, and death occurred in $17 \%$. On the contrary, when less than $50 \mathrm{~mL}$ blood was transfused, symptoms occurred in only $25 \%$ of the patients with no reported deaths [1].

When type B RBCs are transfused to a type O RBC patient, the patient's own anti-B antibodies react with the B-antigen on the type B RBC surface. This antigen-antibody reaction leads to complement reaction, which causes systemic inflammatory reaction such as fever, hypotension and DIC, and hemolysis, which results in the release of free $\mathrm{Hb}$ causing DIC and AKI $[1,3]$.

Complement activation triggered by the antigen-antibody reaction has a direct effect not only on the hemolysis but also on the systemic inflammatory reaction. In particular, $\mathrm{C} 3 \mathrm{a}$ and $\mathrm{C} 5 \mathrm{a}$ bind to the $\mathrm{C} 3 \mathrm{a}$ and $\mathrm{C} 5 \mathrm{a}$ receptors that are expressed on lymphocytes, macrophages, and vascular endothelial cells. This reaction is followed by the production of free radicals, nitric oxide (NO), leukotrienes, and interleukins $[4,5]$. When this occurs in excess, they trigger systemic inflammatory reactions, such as hypotension due to increasing vascular permeability [6] and fever. On mixing of type A or B blood cells with type O whole blood, IL-8 and TNF levels were reported to increase in in vitro experiments $[7,8]$. TNF promotes the release of tissue factors from vascular endothelial cells, resulting in further decrease in thrombomodulin responsible for DIC [9]. Thus, complement activation is also responsible for DIC.

Free hemoglobin enhances vascular permeability, triggering the activation of white blood cells [6]. This leads to further induction of clotting cascade and systemic inflammatory reactions [3]. Free hemoglobin also binds and inhibits NO, resulting in constriction of the vascular 


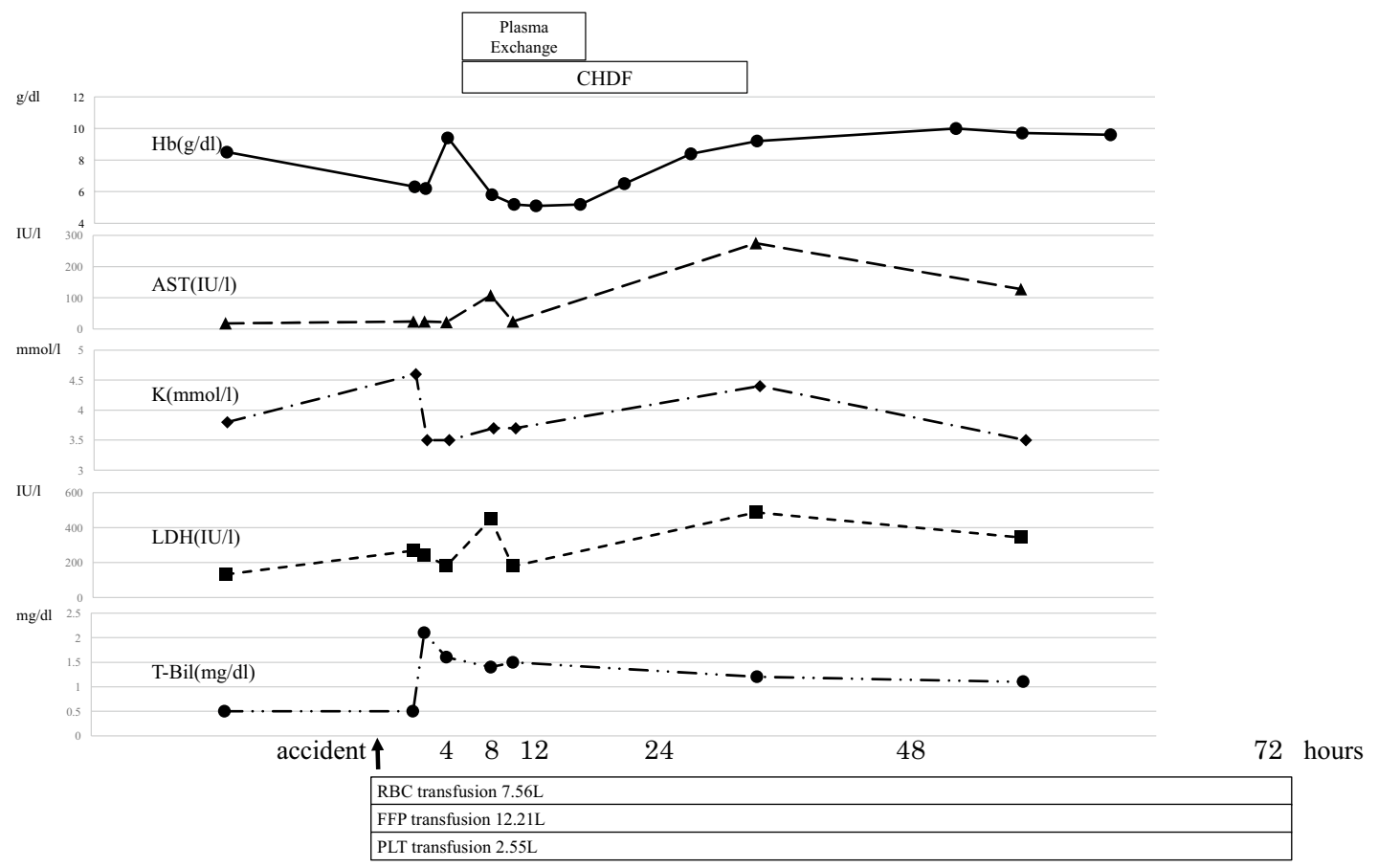

a The changes in the acute hemolytic reaction and the amount of transfusion

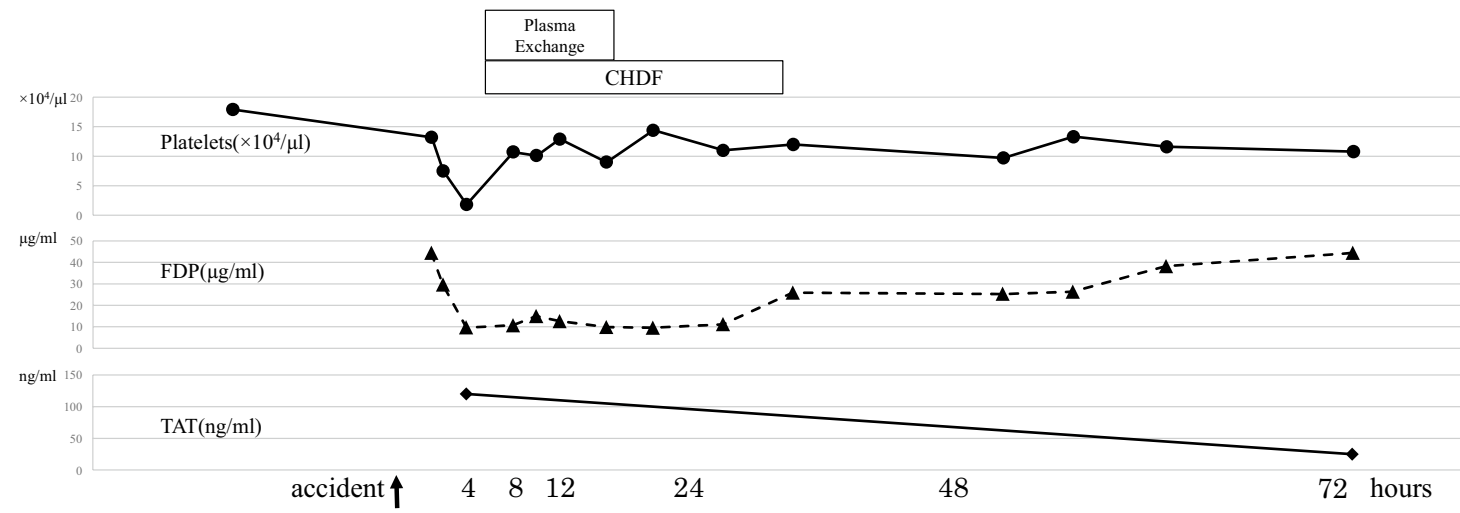

b The progression of dissemination intravascular coagulation (DIC)

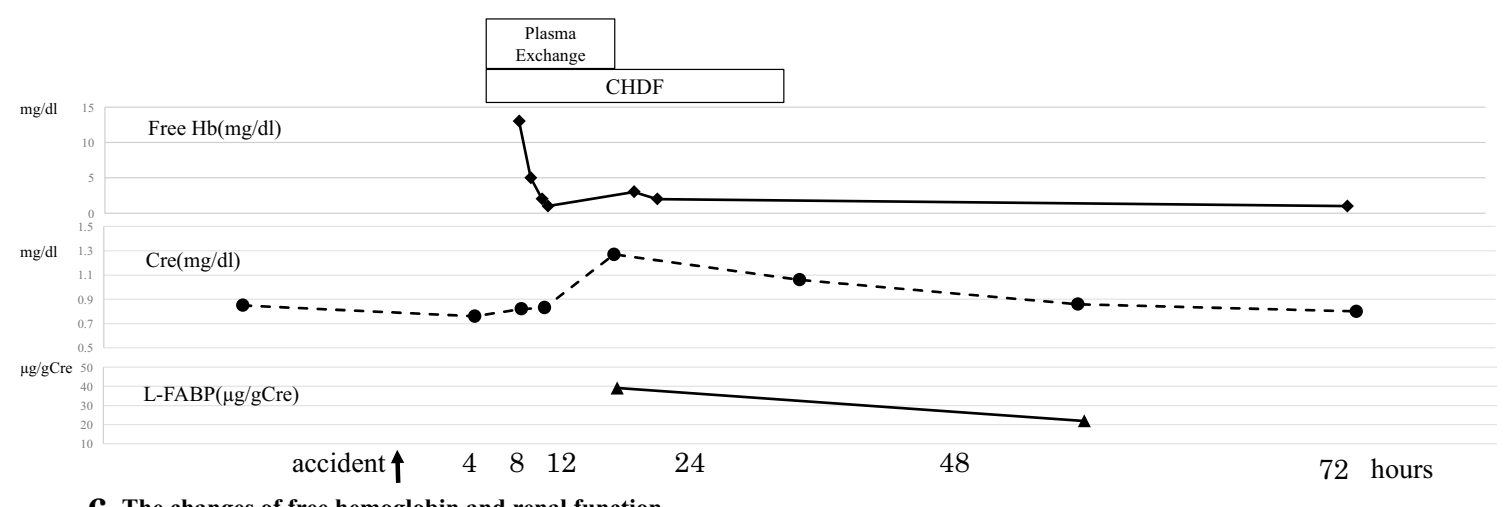

Fig. 1 The overview of the incompatible blood transfusion 
Fig. 2 Changes in the color of plasma

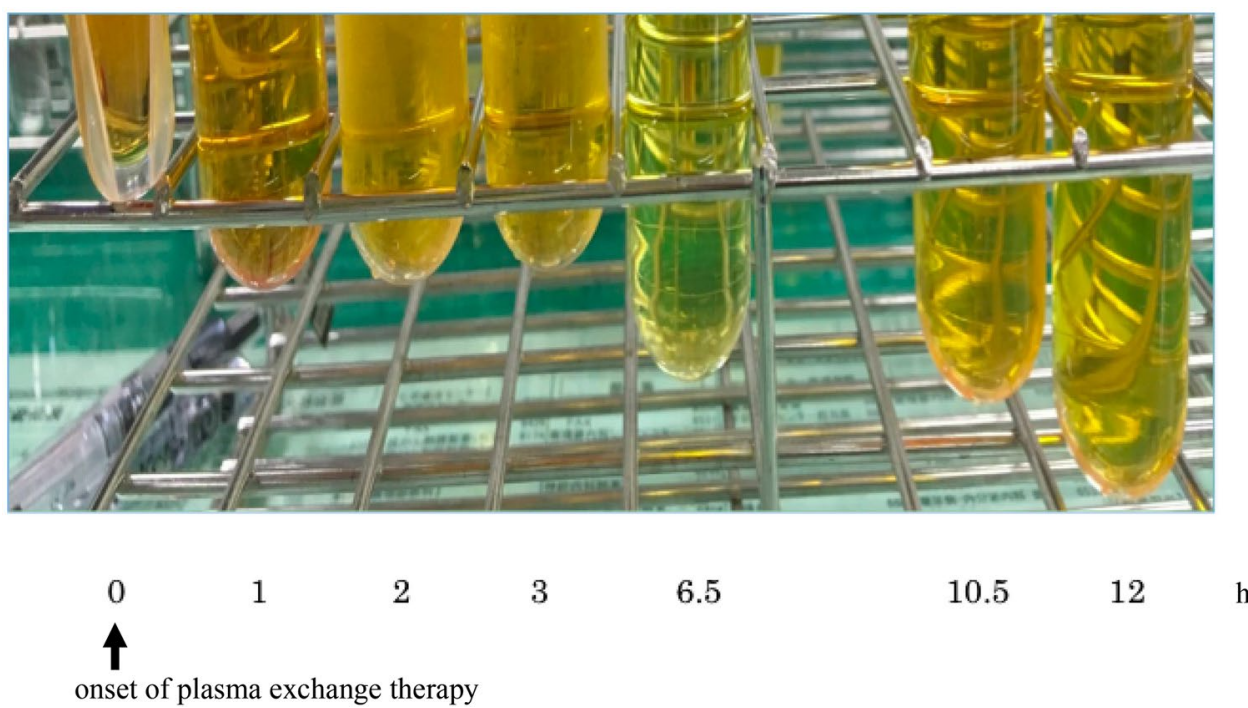

Fig. 3 Changes in anti-B antibody levels

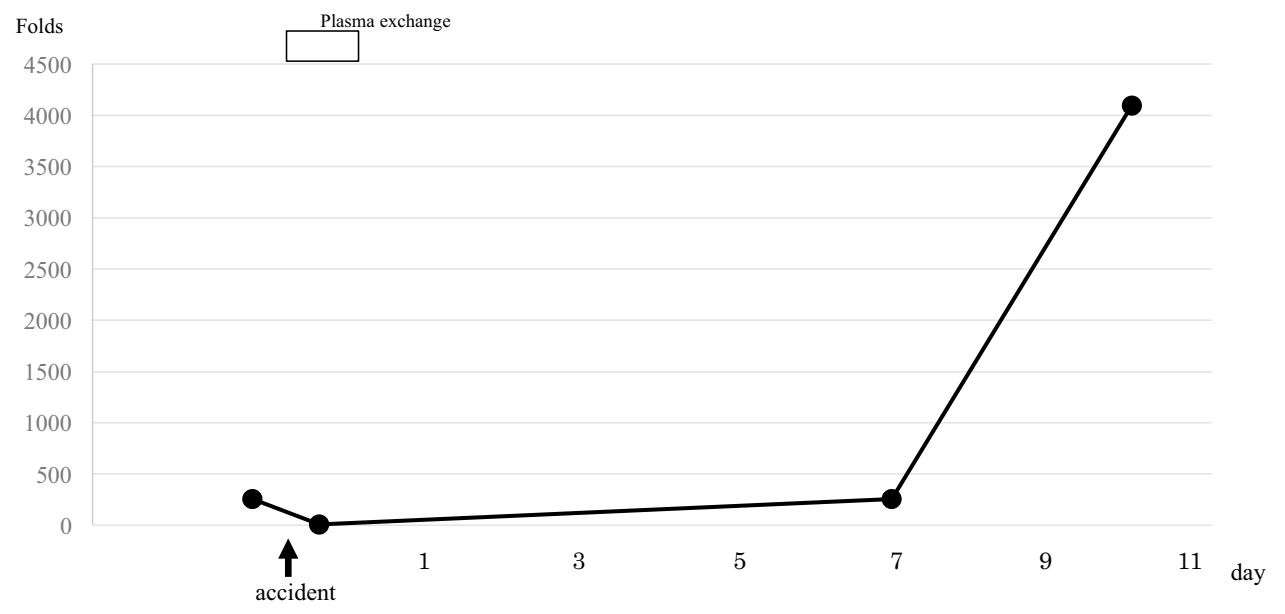

smooth muscles, platelet activation, and platelet clumping $[10,11]$. These mechanisms are consequently responsible for DIC.

AKI is caused by DIC and renal tubular impairment owing to the presence of free hemoglobin [3, 12, 13]. In an experimental monkey model, fibrin clotting was observed within the kidney after an incompatible blood transfusion that suggested the involvement of DIC induced by acute hemolytic reaction [14]. Hemoglobinuria was recently reported to impair the renal tubular barrier, causing oxidative damage to renal tubular cells [12] and the reduction in density of the peritubular capillaries (PTC) [13].

The treatment for incompatible blood transfusion involves a prompt discontinuation of blood transfusion and administration of appropriate supportive therapy. No other clear treatment modality has been established. In recent reports, whole blood exchange transfusion [15] and use of heparin and eculizumab [16] were described; however, there is no established evidence of these treatments. As far as we are aware, no studies on plasma exchange therapy have been reported to date (Table 2 ).

Plasma exchange therapy involves the replacement of plasma in the blood with FFP or 5\% albumin to remove toxic substances in the plasma and supplement insufficient substances [17]. For incompatible blood transfusions, plasma exchange therapy results in the removal of anti-A or anti-B antibodies and the removal of free hemoglobin.

The removal of anti-A or anti-B antibodies can inhibit the antigen-antibody reaction. In ABO-incompatible renal transplants, anti-A or anti-B antibodies are removed by plasma exchange therapy, resulting in successful transplantation. The study by Clark et al. revealed that the lower antibody titer is associated with improved grafting rate [17]. In our case, anti-B antibody titer was low during plasma exchange therapy. We detected type B RBCs from incompatible transfusion at the end of plasma exchange therapy. This suggested that there had been lasting hemolytic reaction during plasma exchange therapy and there had been 
Table 2 Reports on incompatible blood transfusion

\begin{tabular}{|c|c|c|c|c|c|c|}
\hline Patient & Blood type & $\begin{array}{l}\text { Type of transfused } \\
\text { blood and amount }\end{array}$ & Complication & Treatment & Prognosis & References \\
\hline 32-year-old male & $\mathrm{O}$ & Type A, $450 \mathrm{~mL}$ & $\begin{array}{l}\text { Hypotension, acute } \\
\text { hemolysis }\end{array}$ & None & Survived & Janatpour et al. [1] \\
\hline 36-year-old female & $\mathrm{O}$ & Type A, $300 \mathrm{~mL}$ & Hypotension & Support therapy only & Survived & Janatpour et al. [1] \\
\hline 53-year-old female & $\mathrm{O}$ & Type A, $600 \mathrm{~mL}$ & $\begin{array}{l}\text { Fever, increased } \\
\text { blood pressure, } \\
\text { acute hemolysis, } \\
\text { acute renal impair- } \\
\text { ment }\end{array}$ & Support therapy only & Died & Janatpour et al. [1] \\
\hline 60-year-old male & $\mathrm{O}$ & Type A, $1200 \mathrm{~mL}$ & $\begin{array}{l}\text { Hypotension, acute } \\
\text { hemolysis, acute } \\
\text { renal impairment, } \\
\text { DIC }\end{array}$ & Support therapy only & Died & Janatpour et al. [1] \\
\hline 65-year-old male & $\mathrm{O}$ & Type A, $600 \mathrm{~mL}$ & $\begin{array}{l}\text { Acute hemolysis, } \\
\text { acute renal impair- } \\
\text { ment }\end{array}$ & $\begin{array}{l}\text { Support therapy } \\
\text { (hemodialysis for } \\
2.5 \text { weeks) }\end{array}$ & Survived & Janatpour et al. [1] \\
\hline 78-year-old male & $\mathrm{O}$ & Type B, $300 \mathrm{~mL}$ & None & None & Survived & Janatpour et al. [1] \\
\hline 80-year-old male & $\mathrm{O}$ & Unknown & $\begin{array}{l}\text { Hypotension, acute } \\
\text { hemolysis }\end{array}$ & Support therapy only & Died & Janatpour et al. [1] \\
\hline 81-year-old male & A & Type B, $300 \mathrm{~mL}$ & Unknown & Support therapy only & Died & Janatpour et al. [1] \\
\hline PNH patient & $\mathrm{B}$ & Type A, $300 \mathrm{~mL}$ & Acute hemolysis only & Eculizumab, heparin & Survived & Weinstock et al. [16] \\
\hline 64-year-old female & $\begin{array}{l}\text { A (anti-e } \\
\text { antibody } \\
\text { present) }\end{array}$ & $\begin{array}{l}\text { Anti-e antigen- } \\
\text { positive type A, } \\
9600 \mathrm{~mL}\end{array}$ & $\begin{array}{l}\text { Hypotension, acute } \\
\text { hemolysis }\end{array}$ & $\begin{array}{l}\text { Exchange blood trans- } \\
\text { fusion }\end{array}$ & Survived & Irani et al. [15] \\
\hline
\end{tabular}

1 unit $=300 \mathrm{~mL}$

undestroyed type B RBCs at the end of plasma exchange therapy. As AST, LDH, and T.Bil levels were not elevated during plasma exchange therapy, removal of anti-A or anti-B antibodies may help to minimize antigen-antibody reaction and hemolysis in incompatible blood transfusions.

Removal of free $\mathrm{Hb}$ can inhibit DIC and AKI. Duvall et al. described a case where $140 \mathrm{~mL}$ of type A Rh-positive blood was accidentally transfused to a type $\mathrm{O}$ patient and the time required to reach the minimum free hemoglobin level was approximately $24 \mathrm{~h}$ [18]. In our case, free hemoglobin levels decreased from 13 to $2 \mathrm{mg} / \mathrm{dL}$ for $2 \mathrm{~h}$ (Fig. 1c). We demonstrated that a rapid decrease in free hemoglobin could be achieved within $2 \mathrm{~h}$ using plasma exchange therapy and thus gained improvement of DIC and AKI.

CHDF may be a useful adjunct to stabilize hemodynamics during incompatible blood transfusion, as it helped to avoid volume overload. CHDF enabled the patient to be transfused $7.56 \mathrm{~L} \mathrm{RBCs}$ for $72 \mathrm{~h}$ for treatment. This large blood transfusion amount was similar to the whole blood exchange transfusion, which may thus be effective in incompatible blood transfusion.

In conclusion, we described a case of incompatible blood transfusion successfully treated with plasma exchange therapy and CHDF. This report shows that plasma exchange therapy and CHDF are potentially useful for inhibiting the onset and progression of acute hemolytic reactions, DIC, and AKI.

\section{Compliance with ethical standards}

Conflict of interest The authors have declared that no conflict of interest exists.

Research involving human participants and/or animals This article does not contain any studies on human participants or animals performed by any of the authors.

Informed consent Informed consent was obtained from all individual participants included in the study.

Open Access This article is distributed under the terms of the Creative Commons Attribution 4.0 International License (http://creativeco mmons.org/licenses/by/4.0/), which permits unrestricted use, distribution, and reproduction in any medium, provided you give appropriate credit to the original author(s) and the source, provide a link to the Creative Commons license, and indicate if changes were made.

\section{References}

1. Janatpour KA, Kalman ND, Jensen HM, Holland PV. Clinical outcomes of ABO-incompatible RBC transfusions. Am J Clin Pathol. 2008;129:276-81. 
2. Linden JV, Wagner K, Voytovich AE, Sheehan J. Transfusion errors in New York state: an analysis of 10 years' experience. Transfusion. 2000;40:1207-13.

3. Klein HG, Anstee DJ. Mollison.'s blood transfusion in clinical medicine. 12th ed. Wiley: Blackwell; 2014.

4. Butler J, Parker D, Pillai R, Shale DJ, Rocker GM. Systemic release of neutrophil elastase and tumour necrosis factor alpha following ABO incompatible blood transfusion. Br J Haematol. 1991;79:525-6.

5. Davenport RD, Polak TJ, Kunkel SL. White cell-associated procoagulant activity induced by ABO incompatibility. Transfusion. 1994;34:943-9.

6. Wagener FA, Eggert A, Boerman OC, Oyen WJ, Verhofstad A, Abraham NG, et al. Heme is a potent inducer of inflammation in mice and is counteracted by heme oxygenase. Blood. 2001;98:1802-11.

7. Davenport RD, Strieter RM, Standiford TJ, Kunkel SL. Interleukin-8 production in red blood cell incompatibility. Blood. 1990;76:2439-42.

8. Davenport RD, Strieter RM, Kunkel SL. Red cell ABO incompatibility and production of tumour necrosis factor-alpha. Br J Haematol. 1991;78:540-4.

9. Capon SM, Goldfinger D. Acute hemolytic transfusion reaction, a paradigm of the systemic inflammatory response: new insights into pathophysiology and treatment. Transfusion. 1995;35:513-20.

10. Simionatto CS, Cabal R, Jones RL, Galbraith RA. Thrombophlebitis and disturbed hemostasis following administration of intravenous hematin in normal volunteers. Am J Med. 1988;85:538-40.

11. Rother RP, Bell L, Hillmen P, Gladwin MT. The clinical sequelae of intravascular hemolysis and extracellular plasma hemoglobin: a novel mechanism of human disease. JAMA. 2005;293:1653-62.

12. Tabibzadeh N, Estournet C, Placier S, Perez J, Bilbault H, Girshovich A, et al. Plasma heme-induced renal toxicity is related to a capillary rarefaction. Sci Rep. 2017;7:40156.

13. Deuel JW, Schaer CA, Boretti FS, Opitz L, Garcia-Rubio I, Baek $\mathrm{JH}$, et al. Hemoglobinuria-related acute kidney injury is driven by intrarenal oxidative reactions triggering a heme toxicity response. Cell Death Dis. 2016;7:e2064.

14. Lopas H, Birndorf NI, Robboy SJ. Experimental transfusion reactions and disseminated intravascular coagulation produced by incompatible plasma in monkeys. Transfusion. 1971;11:196-203.

15. Irani MS, Karafin MS, Ernster L. Red cell exchange to mitigate a delayed hemolytic transfusion reaction in a patient transfused with incompatible red blood cells. J Clin Apher. 2017;32:59-61.

16. Weinstock C, Möhle R, Dorn C, Weisel K, Höchsmann B, Schrezenmeier $\mathrm{H}$, et al. Successful use of eculizumab for treatment of an acute hemolytic reaction after ABO-incompatible red blood cell transfusion. Transfusion. 2015;55:605-10.

17. Clark WF, Huang SS, Walsh MW, Farah M, Hildebrand AM, Sontrop JM. Plasmapheresis for the treatment of kidney diseases. Kidney Int. 2016;90:974-84.

18. Duval CP, Alter HJ, Rath CE. Hemoglobin catabolism following a hemolytic transfusion reaction in a patient with sickle cell anemia. Transfusion. 1974;14:382-7. 